Harald Prüss, MD

Christian Hoffmann, MD

Werner Stenzel, MD

Sandra Saschenbrecker, $\mathrm{PhD}$

Martin Ebinger, MD

Neurol Neuroimmunol Neuroinflammation

2014;1:e14; doi: 10.1212/ NXI.0000000000000014

\section{A CASE OF INFLAMMATORY PERIPHERAL NERVE DESTRUCTION ANTEDATING ANTI-NMDA RECEPTOR ENCEPHALITIS \\ OPEN}

NMDA receptor (NMDAR) antibody encephalitis is the second most common autoimmune encephalitis after acute disseminated encephalomyelitis, presenting with a multistage clinical progression with prodromal signs, psychiatric abnormalities, reduced levels of consciousness, epileptic seizures, dyskinesias, and autonomic dysfunction. ${ }^{1}$ Pathogenic NMDAR autoantibodies downregulate NMDARs in cultured hippocampal neurons ${ }^{2}$ and after injection into the rat brain. ${ }^{3}$ Teratomas are common in adult women and are believed to trigger the antibody response against NMDARs by ectopically expressing neuronal antigens. ${ }^{1}$ Causal factors in tumor-negative patients are largely unknown. Recent studies showed that infectious encephalitides with herpes simplex virus (HSE) are associated with the generation of NMDAR antibodies $^{4}$ and that antibodies cause immunotherapy-responsive relapsing symptoms post-HSE. ${ }^{5}$ It is unknown, however, whether further types of neuronal damage can trigger a secondary immune response leading to NMDAR encephalitis.

Case report. A previously healthy 75-year-old man was referred with confusion, disorientation, and agitation. History revealed signs of neuropathy with ascending pain and numbness in his legs starting at least 3-4 weeks (but not $>8$ weeks) prior to referral; a friend reported progressive difficulties in walking and frequent falls during this time. Lumbar puncture showed normal cell count $(5 / \mu \mathrm{l})$ but high protein $(>1,047 \mathrm{mg} / \mathrm{L})$. Viral encephalitis was suspected and acyclovir was started until PCR for herpes simplex virus (HSV) and varicella-zoster virus showed negative results. Head MRI was unremarkable, showing mild generalized atrophy. No infectious agents were detected in serum and CSF, and NMDAR antibodies were below detection threshold (figure).

Encephalopathy progressed and the patient fluctuated between severe agitation with hyperkinetic movements and unresponsiveness, later developing unexplained fever and respiratory distress requiring mechanical ventilation. EEG showed bilateral slowing. Repeated serum and CSF testing showed increasing titers of immunoglobulin (Ig) G-NMDAR antibodies (figure). NMDAR antibody testing was performed using a standardized laboratory assay ${ }^{2}$ (figure); further antibodies against neural antigens (AMPAR, $\mathrm{GABA}_{\mathrm{B}} \mathrm{R}, \mathrm{GlyR}$, LGI1, CASPR2, AQP4, DNER(Tr), GAD65, Hu, Yo, Ri, Ma/Ta, amphiphysin, MAG, myelin) were absent (Euroimmun, Lübeck, Germany).

CT with contrast enhancement and PET scan showed no evidence of a tumor; brain PET revealed bilateral hypometabolism in thalamus, caudate nucleus, and cerebellum. Immunosuppressive therapy was started with methylprednisolone and IVIg. Four cycles of plasma exchange and 2 doses of 1,000 mg rituximab were started after 6 and 12 weeks of limited improvement, respectively. Therapy resulted in marked improvement of leg pain, weakness, and NMDAR encephalitis, paralleled by loss of antibodies (figure).

Differential diagnosis of the concomitant severe neuropathy included nerve conduction studies, which showed sensorimotor axonal and demyelinating neuropathy predominantly affecting the legs (compound muscle action potential of right tibial nerve was reduced, nerve conduction velocity was delayed, and there were no reproducible recordings from peroneal and sural nerves). EMG was refused by the patient. Reflexes were normal, and there were no atrophies or fasciculations. Sural nerve biopsy 3 months after referral showed severe reduction of myelinated fibers but also strong axonal degeneration and single axon regeneration clusters (figure). Diagnosis of acute neuritis was established. There were no findings supporting vasculitis, paraproteinemia, vitamin $\mathrm{B}_{12}$ deficiency, diabetes, hepatitis $\mathrm{C}$ virus, HIV, or porphyria as alternative diagnoses.

Nine months after initial presentation he showed no dyskinesias, no signs of autonomic or psychiatric dysfunction, and normal consciousness and attention. Motor function and leg pain were markedly improved whereas electrophysiology was unchanged. Persisting anterograde memory deficits suggest postencephalitic residuum.

Discussion. The case describes how subacute onset of severe neuritis antedates classical NMDAR encephalitis. The temporal relationship of symptoms and antibody kinetics makes it unlikely that both diseases result from a shared precipitating factor, although such associations were shown for NMDAR encephalitis and demyelinating disorders. ${ }^{6}$ We hypothesize that NMDAR antibodies represent a secondary immune response to massive 
A

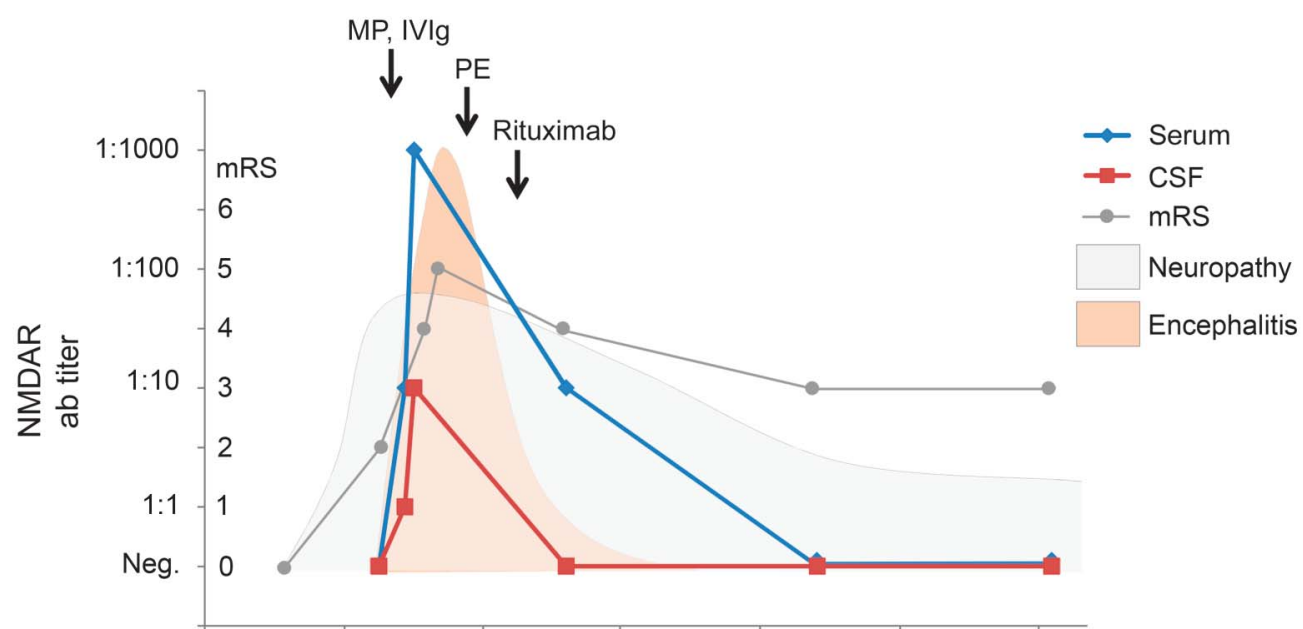

01:06.2012 01:09.2012 01:12.2012 $01: 03.2013 \quad 01: 06.2013 \quad 01: 09.2013 \quad 01: 12.2013$
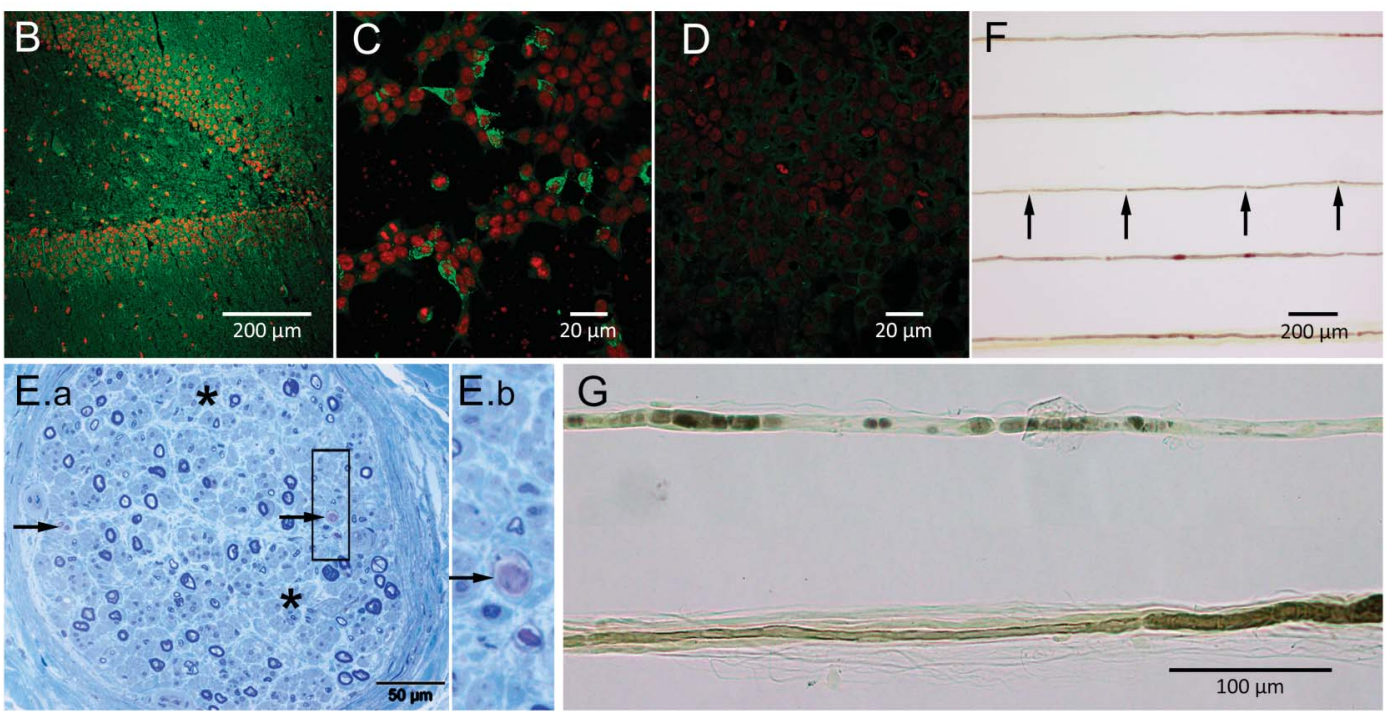

(A) Approximately 3-4 weeks after onset of peripheral neuropathy, NMDAR antibody (ab) titers started to appear in CSF (red) and serum (blue). NMDAR encephalitis showed response to immunotherapy with methylprednisolone (MP), IV immunoglobulin (IVIg), plasma exchange (PE), and rituximab. Curves for neuropathy and encephalitis demonstrate global clinical impression (arbitrary units) to visualize the sequence of clinical symptoms. $m R S$ = modified Rankin Scale. (B-D) Patient's serum (green, Alexa Fluor 488, Jackson ImmunoResearch, Suffolk, UK) showed the typical pattern in rat hippocampus (dilution 1:400, B) and NMDAR-transfected HEK293 cells (C) but not control-transfected cells (D). Red nuclear stain was performed with TO-PRO-3 iodide (Invitrogen, Karlsruhe, Germany). (E.a) Semithin section stained by methylene blue illustrates severe reduction of myelinated fibers, affecting both thin and thickly myelinated fibers. Also, profound axonal loss (asterisks), acute axonal degeneration (arrows), and single axon regeneration clusters are visible (box E.b: higher magnification). (F) Teased fibers show short internodal segments (arrows). (G) Higher magnification demonstrates hypomyelinated and shortened segments (sign of demyelination) and alignment of ovoids (sign of acute axonal degeneration).

destruction of peripheral nerve proteins as shown in sural nerve biopsy, also supported by the temporal relationship between neuritis onset and NMDAR antibodies. It is well known that peripheral nerves contain high amounts of NMDAR protein, ${ }^{7}$ which becomes phagocytosed after disintegration of the nerve. Transport to lymphoid organs may then trigger an immune response resulting in encephalitis.

In this way, the case adds a novel mechanism to the most relevant question: which pathophysiologic steps lead to NMDAR encephalitis? While teratomas have been shown to express NMDAR protein and are associated with NMDAR encephalitis, infectious encephalitides with HSV were recently added to the still-small list of etiologies. ${ }^{4,5}$ The present case suggests that inflammatory neuropathies may also trigger a secondary autoimmune response leading to severe encephalitis. Whether less obvious damage to peripheral neuronal tissue can under certain conditions trigger an immune response with formation of pathogenic 
autoantibodies and NMDAR encephalitis is an intriguing question.

From the Department of Neurology and Experimental Neurology (H. P., C.H., M.E.) and Department of Pathology (W.S.), CharitéUniversitätsmedizin Berlin; German Center for Neurodegenerative Diseases (DZNE) Berlin (H.P.); and Institute for Experimental Immunology (S.S.), affiliated with Euroimmun, Lübeck, Germany. Author contributions: Design or conceptualization of the study: Priuss, Ebinger. Analysis or interpretation of the data: Priiss, Hoffmann, Stenzel, Saschenbrecker, Ebinger. Drafting or revising the manuscript: Prüss, Hoffmann, Stenzel, Saschenbrecker, Ebinger.

Study funding: No targeted funding reported.

Disclosure: H. Prüss, C. Hoffmann, W. Stenzel, and M. Ebinger report no disclosures relevant to the manuscript. S Saschenbrecker is full-time employee of Euroimmun. Go to Neurology.org/nn for full disclosures. The Article Processing charge was paid by Charité Universitätsmedizin Berlin.

This is an open access article distributed under the terms of the Creative Commons Attribution-Noncommercial No Derivative 3.0 License, which permits downloading and sharing the work provided it is properly cited. The work cannot be changed in any way or used commercially.

Received February 11, 2014. Accepted in final form April 28, 2014. Correspondence to Dr. Prüss: harald.pruess@charite.de
1. Titulaer MJ, McCracken L, Gabilondo I, et al. Treatment and prognostic factors for long-term outcome in patients with anti-NMDA receptor encephalitis: an observational cohort study. Lancet Neurol 2013;12:157-165.

2. Prüss H, Dalmau J, Harms L, et al. Retrospective analysis of NMDA receptor antibodies in encephalitis of unknown origin. Neurology 2010;75:1735-1739.

3. Hughes EG, Peng X, Gleichman AJ, et al. Cellular and synaptic mechanisms of anti-NMDA receptor encephalitis. J Neurosci 2010;30:5866-5875.

4. Prüss H, Finke C, Höltje M, et al. N-methyl-D-aspartate receptor antibodies in herpes simplex encephalitis. Ann Neurol 2012;72:902-911.

5. Armangue T, Leypoldt F, Malaga I, et al. Herpes simplex virus encephalitis is a trigger of brain autoimmunity. Ann Neurol 2013;75:317-323.

6. Titulaer MJ, Höftberger R, lizuka T, et al. Overlapping demyelinating syndromes and anti-N-methyl-D-aspartate receptor encephalitis. Ann Neurol 2014. doi: 10.1002/ana.24117.

7. Pagadala P, Park CK, Bang S, et al. Loss of NR1 subunit of NMDARs in primary sensory neurons leads to hyperexcitability and pain hypersensitivity: involvement of $\mathrm{Ca}(2+)-$ activated small conductance potassium channels. J Neurosci 2013;33:13425-13430. 


\section{Neurology \\ Neuroimmunology \& Neuroinflammation}

\section{A case of inflammatory peripheral nerve destruction antedating anti-NMDA receptor encephalitis \\ Harald Prüss, Christian Hoffmann, Werner Stenzel, et al. \\ Neurol Neuroimmunol Neuroinflamm 2014;1; \\ DOI 10.1212/NXI.0000000000000014}

This information is current as of May 22, 2014

Updated Information \&

Services

References

Citations

Subspecialty Collections

Permissions \& Licensing

Reprints including high resolution figures, can be found at:

http://nn.neurology.org/content/1/2/e14.full.html

This article cites 6 articles, 2 of which you can access for free at: http://nn.neurology.org/content/1/2/e14.full.html\#\#ref-list-1

This article has been cited by 1 HighWire-hosted articles: http://nn.neurology.org/content/1/2/e14.full.html\#\#otherarticles

This article, along with others on similar topics, appears in the following collection(s):

All Clinical Neurology

http://nn.neurology.org//cgi/collection/all_clinical_neurology

Autoimmune diseases

http://nn.neurology.org//cgi/collection/autoimmune_diseases

Encephalitis

http://nn.neurology.org//cgi/collection/encephalitis

Information about reproducing this article in parts (figures,tables) or in its entirety can be found online at:

http://nn.neurology.org/misc/about.xhtml\#permissions

Information about ordering reprints can be found online: http://nn.neurology.org/misc/addir.xhtml\#reprintsus

Neurol Neuroimmunol Neuroinflamm is an official journal of the American Academy of Neurology.

Published since April 2014, it is an open-access, online-only, continuous publication journal. Copyright $($ ) 2014 American Academy of Neurology. All rights reserved. Online ISSN: 2332-7812.

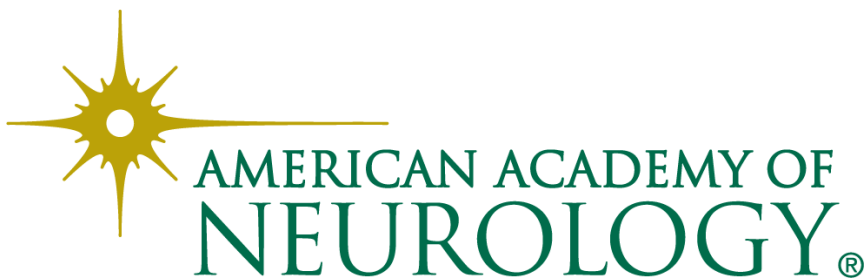

